\section{Proprietary Interest: Merchants, Journalists, and Antimonopoly in the 1880 s}

Richard R. John

"Many good people have imagined a bogey monster that doesn't exist. They have accepted as facts the fancies of sensational journalism." So declared business lobbyist Francis B. Thurber in December 1899 in the Journal of Social Science, in deploring popular hostility toward Standard Oil, the American Sugar Refining Company, and other corporate behemoths. ${ }^{1}$ Journalists were wrong to demonize these giant organizations, Thurber warned, by conjuring up the "bogey monster" of monopoly. In fact, these giant organizations had a "right to combine" - subject to a "due regard to the rights of others"-since, as history demonstrated, economic consolidation would lower prices and increase output, making it a boon for the consumer. ${ }^{2}$

Thurber's exasperation with the popular press was rooted in his conviction that irresponsible journalists were fueling a wrongheaded legal crusade to criminalize the economically sound, well-intentioned, and morally praiseworthy mergers and acquisitions that had been undertaken recently by some of the country's largest and most powerful corporations. To check corporate abuse, Congress had in 1890 enacted a brief but sweeping law, known as the Sherman Act, which had made it a felony for anyone to monopolize, or even to "attempt to monopolize," any trade or form of commerce "among the several States, or with foreign nations." From Thurber's perspective, the Sherman Act was a travesty of justice that had plainly been inspired by a "wave of radical public opinion" that had originated among economically illiterate farmers and workers and that would be amplified by demagogic politicians and a scurrilous "penny journalism." Even "our popular presi-" dent" Theodore Roosevelt, Thurber elaborated in 1905, was "liable to err in his impulses unless he studies this subject more deeply than he has as yet."

Thurber's lament is a pointed reminder of the complex tangle of interests and ideology that shaped the late nineteenth-century media campaign to regulate the conduct of large and powerful corporations. This media campaign would reach its apotheosis in the decade immediately preceding the enactment of the Sherman. Act and has come to be known to contemporaries and historians alike as "antimonopoly." This story is familiar to historians of the period, yet it has only rarely been subjected to critical scrutiny. This essay tries to set the record straight.

It has long been conventional for bistorians-following, if unwittingly, obviously partisan corporate apologists like Thurber-to trace the late nineteenth-century antimonopoly movement to the grievances of farmers and laborers outraged by the excesses of big business, making it, as it were, the latest installment in a perennial contest between the many and the few. This oft-told story is not entirely mistaken. Farm and labor publications had lambasted railroad corporations since at least the 1870s. Yet it is oversimplified and in certain factual details misleading. In fact, the antimonopoly movement that crested in the 1880s-the decade in which it loomed largest in public life-received its primary impetus not from farmers and workers, but rather from some of the country's wealthiest and most influential merchants-the most vocal of whom were based in New York, Brooklyn, Chicago, and San Francisco-whose anticorporate, pro-proprietary worldview was powerfully amplified by a small but influential cadre of reform-minded journalists. These merchants popularized a critique of corporate power that would shape American public life for decades to come.

The wealthiest and most powerful merchants in the 1880 s were not retailers (Sears would not build its first retail store until the 1920s), but, instead, wholesalers and shippers. Most merchants, including some of the wealthiest and most powerful, did not operate their businesses as statechartered corporations that managed other people's money. Instead, their businesses took the form of wholly owned proprietorships-often partnerships with two or more principals-that had been organized under the common law. Historians sometimes assume that "big business" vanquished all comers in late nineteenth-century America. In reality, the "incorporation" of America was slow and halting. Even Andrew Carnegie's vast steel empire was organized not as a corporation but as a proprietorship. The phrase "big 
business" itself would not gain widespread currency until the twentieth century. The economic and moral superiority of the proprietorship over the corporation was a truism for well-educated Americans who reasoned, not implausibly, that proprietorships fostered autonomy while corporations bred dependency. This truism was also an article of faith for big-city merchants. who remained in the 1880 s one of the nation's most tightly organized political blocs. Corporations were obviously powerful, yet few assumed that their ascendancy was inevitable, while the proprietary-corporate moral equation would not shift in a decisive way until World War I.

While proprietorships and corporations were each capitalistic, they differed fundamentally in one key dimension. Corporations had been granted under state law unlimited liability for the losses they incurred; proprietorships had not. Since the wealth of almost every merchant was tied up in his business, this meant that, should he fail-as thousands would during the Panic of 1893 - he was ruined. ${ }^{6}$

The vulnerability of merchants to financial collapse best explains why the antimonopoly movement found such a sympathetic reception in the press. It was not outsiders, but insiders, who fanned the flames. The corporations that New York City antimonopolists inveighed against with the greatest fervor in the 1880s were localized in one of three sectors: transportation (the New York \& Hudson River Railroad), communications (Western Union), and energy (Standard Oil). Each threatened the economic interests of the city's merchants, though in different ways. The New York \& Hudson Railroad and Western Union had it in their power to alter the terms of trade, cutting the merchants' margins to the bone. The threat posed by Standard Oil was less existential, though no less real: the noxious fumes that spewed forth from the East River refinery that it operated just north of Brooklyn fouled the air, imperiled property values, and undermined confidence in the self-regulating mechanisms of the market economy.

Journalists recognized the merchants' predicament and responded accordingly. The editorial positions of most influential big-city newspapers in the late nineteenth century, as in most periods of American history, remained closely aligned with the country's commercial elite, which in the 1880 s continued to be dominated not by corporations, but by merchants. For this reason alone, it is thus not surprising that the antimonopoly movement found support in several of the nation's most influential newspapers, including the Chicago Tribune and the New York World?
Thurber's relationship to the antimonopoly movement is especially suggestive. For several decades prior to 1893 , he had been a proprietor of Thurber, Whyland \& Company, a large and successful Manhattan-based grocery wholesaler that had acquired an enviable reputation as one of country's largest importers of coffee and tea. Thurber would fail in the Panic of 1893, ending his business career. Financially ruined, Thurber retrained as a lawyer, an unusual decision in an age in which midlife career changes remained uncommon.

Thurber's legal expertise provided him with the necessary credentials to hang out a shingle as a business lobbyist. Thurber also had an additional, perhaps even more important, qualification for his new job. For in the years prior to his bankruptcy, Thurber himself had been one of the very antimonopoly agitators he now cautioned the public against. The primary impetus for the antimonopoly movement that he now inveighed against, Thurber knew well, lay neither on the farm nor in the factory. Rather, it had been the brainchild of big-city proprietary capitalists like himself-that is, before he had gone bankrupt-an inconvenient fact now that he had switched sides, yet one that reveals much about media politics in the 1880 s, the decade in which the antimonopoly movement would exert its greatest influence over the public imagination.

Much of the historical writing on the late nineteenth-century antimonopoly movement has viewed it through the lens of the Sherman Act, which is unsurprising, since for much of the twentieth century this law remained a cornerstone of U.S. economic policy. This essay approaches the topic from a different angle. Instead of treating the Sherman Act as the first chapter in a twentieth-century grand narrative of business challenge and government response, it.casts a spotlight on the world out of which this law emerged. In this world, the most influential actors were neither farmers nor workers, but merchants and the journalists who publicized their grievances-voices often marginalized in standard accounts of late nineteenth-century public life.

Farmers and workers, to be sure, had good reason to oppose economic consolidation. Yet it would be an exaggeration to put them at the center of the antimonopoly movement of the $1880 \mathrm{~s}$. Other voices were far more influential, especially in the big-city press, which was where the movement found its most enduring expression. The antimonopoly movement of the $1880 \mathrm{~s}$ did not begin on the periphery and move to the center. On the contrary, it originated in the nation's commercial centers and only later migrated to 
the agricultural hinterland. ${ }^{8}$ Many ideas and images that originated in the big-city press would eventually find their way into farm and labor publications. Yet it would be a mistake to overlook their metropolitan-mercantile pedigree. The ubiquitous "robber baron" metaphor, for example, long an antimonopoly rallying cry, had its roots in historical accounts of medieval German commerce, and was initially popularized by well-to-do East Coast merchants and their journalistic devotees. ${ }^{9}$ It should, similarly, come as no surprise that the antimonopoly rationale for government ownership of the telegraph had been widely discussed by merchants and journalists in the big-city press for several decades before it would find its way onto the Populist Party platforms in 1892 and $1896^{10}$

Antimonopoly is easily misunderstood. In the main, its supporters were neither nostalgic defeniders of a small-scale, agrarian society of self-sufficient husbandmen, nor anticapitalistic proponents of a workers' utopia. Contrary to what is sometimes assumed, they did not necessarily oppose economic consolidation. In fact, many antimonopolists deplored "cutthroat" competition-a presumption widely shared by the populists, as Charles Postel has recently demonstrated - and more than a few actually regarded the existing degree of economic consolidation as too low." The problem with giant organizations for these antimonopolists was not that they were too large, but that they were too small: economic consolidation, if properly regulated, could foster economies of scale that could benefit the many as well as the few. At its core, antimonopoly was less about economics than morality: corporations were dangerous not because they were too big, but rather because they had become too powerful to operate unrestrained by law-and, in particular, too independent of the salutary regulatory mechanism of market competition.

"Antimonopoly" in the 1880s was a capacious term that could refer to one of three related yet distinct responses to economic consolidation. Openaccess antimonopolists derided economic consolidation as the unnatural by-product of political collusion and tried to reverse it; consolidationists regarded economic consolidation as irreversible and tried to minimize its ill effects; nationalists lauded economic consolidation as a first step on the path toward government ownership. Each built on the worldview of the wealthy and powerful merchants who in the 1880 s remained highly respected moral arbiters with considerable influence in the press. No antimonopolist viewed with equanimity the possibility that the common-law proprietorship might one day be supplanted by the state-chartered corporation as the country's dominant economic institution, or, for that matter, that corporate publicists would one day identify big business with the country's most cherished civic ideals. The valorization of managerial capitalism and the idealization of "free enterprise". remained in the future. And while not all antimonopolists were nationalists, most regarded government ownership of certain large-scale enterprises with relative equanimity: not until World War I, it is worth recalling, would government ownership of the railroad and the telegraph slip off the national political agenda..$^{12}$ This essay does not chart the rise of managerial capitalism, which would receive a vital impetus during the opening decades of the twentieth century and would be largely complete by $1940 .{ }^{13}$ Instead, it surveys how an earlier generation of Americans thought about monopoly, what it proposed to do about it, and why its assault upon big business took the form that it did.

The oldest and in some ways the most enduring antimonopoly appeal regarded economic consolidation as the unnatural by-product of political collusion. Open access was its byword, barriers to entry its bette noire. The best kind of regulation was competition, and if lawmakers could be persuaded to eliminate the restraints that impeded the free flow of commerce, market forces would do the rest.

Open-access antimonopolism had broad support among wholesalers and shippers eager to lower prices on the movement of goods and services. It was also a favorite of insurgent promoters eager to challenge entrenched incumbents. It was for this reason that, not entirely implausibly, it proved appealing for a brief period in the 1870s to the notorious financier Jay Gould. Gould had invested in an insurgent telegraph network provider to challenge the incumbent, Western Union, and proclaimed himself an antimonopolist to rally support. Open-access antimonopolism also had many champions in the press-sometimes in earnest, yet more than occasionally as a feint to bamboozle unwary investors. ${ }^{14}$

The presumption that monopoly was unnatural was taken for granted by many critics of the railroad and the telegraph, two of the central pillars of the emerging corporate order. To make their case, these critics pointed to the raft of special privileges that Congress had bestowed on continent-spanning railroads, mostly in the form of generous land grants-subsidies that critics then and now contended had prematurely hastened railroad expansion..$^{15}$ Further proof that the market was rigged was the consolidation in 1866 of 
Western Union as the country's dominant telegraph network provider. Whether or not the telegraph market could have been credibly contested after 1866 is beside the point. The fact remains that, in the thirty-six-year period between the opening of the first fee-for-service telegraph line in April 1845 and the takeover of Western Union by financier Jay Gould in January 1881, many of Western Union's critics assumed that the telegraph market would have been open to new entrants had Western Union not unfairly lobbied Congress and manipulated the press. ${ }^{16}$

Among the many journalists to find open access compelling was Frank Bellew, a talented illustrator who is best remembered today as one of the first cartoonists to render the American folk icon "Uncle Sam" in visual form." The special privileges that lawmakers had lavished on the railroad, Bellew maintained in a series of hard-hitting front-page antimonopoly cartoons that ran in the New York Daily. Graphic in the 1870s, were a direct assault on everything the country stood for.

While the Daily Graphic is largely forgotten today, it had the distinction of being the furst daily newspaper in the United States to run illustrations in every issue, an innovation that obliged its editors to search far and wide for suitable content. The ancestor of the modern tabloid, it appealed primarily to novelty-seeking New Yorkers, who were joined by a sprinkling of curious outsiders who subscribed to a weekly edition that they received in the mail. In their quest for new material, the Daily Graphic's illustrators invented much of the visual iconography that would later become a ubiquitous feature of the popular press. Its cartoons were, quite literally, cartoonish: vivid, hardhitting, and unsubtle, they helped establish a gallery of viscerally appealing archetypes-the "octopus," the "robber baron," "the politico"-that would long remain a foxture in the iconography of political reform. ${ }^{18}$

It is, of course, hard to know how many Americans saw Bellew's antimonopoly cartoons, let alone how they reacted. Yet there can be no question but that the iconography that he pioneered would be refined and elaborated by his successors for many decades, before it would be repurposed as a teaching tool in the U.S. history classroom at both high school and college levels--and also, most recently, as an educational resource on the web. ${ }^{19}$

The most arresting of Bellew's antimonopoly cartoons built on the conceit that the manipulation of the political process by corporate lobbyists had transmogrified the railroad-exhibit $A$ of the perils of economic consolidation-into a rampaging monster. Emboldened by its nefarious legislative triumphs, the railroad-monster set its sights on the levers of power.
The monster Bellew had in mind had a distinctly European, high-culture pedigree. This should come as no surprise: few antimonopoly icons were born in the United States. Bellew was an English immigrant, and, prior to his arrival in the United States, had served an apprenticeship in London drawing satirical sketches for the English cornic magazine Punch. When Bellew depicted the railroad as an octopus, for example-a convention that he may well have invented-he drew for inspiration on Victor Hugo's 1866 novel Toilers of the Sea. Bellew's monster, like Hugo's, ensnared an innocent person in its tentacles. For Hugo, the victim was a fisherman; for Bellew, a young woman who symbolized "Columbia," a personification of the republic's civic ideals. Wrapped in the American flag, Columbia struggled to keep the Constitution out of the clutches of the voracious monster, which had already devoured "congressional honor" (Figure 1.1). ${ }^{20}$

The most celebrated of Bellew's antimonopoly cartoons took its inspiration from another literary monster, the malformed giant in Mary Shelley's Frankenstein (1818). For Bellew, the railroad became the vicious creature that Shelley's mad scientist brought to life. In the earliest of Bellew's Frankensteininspired cartoons, the mad scientist, outfitted as Uncle Sam; looked on in horror as the smoke-belching railroad-monster-nourished at the trough of "public lands" and trussed with a belt marked "R.R. monopoly"-sprang to life, crumpling the Constitution in his metallic hand. ${ }^{21}$ In a later and betterknown version of this cartoon, the railroad-monster, having escaped from the scientist's laboratory, terrorized, a prostrate country. In one hand the monster wielded a club marked "capital"; in the other, he waved aloft the torn mantle of "judicial ermine." "Agriculture, Commerce and Manufacture Are All in My Power," the monster exulted, adding ominously that his ultimate "Interest" was the "Higher Law of American Politics."22

High-culture iconography also featured prominently in Bellew's "Modern Laocoön," another railroad-monster antimonopoly cartoon that drew its inspiration from European art. In this cartoon, Bellew reinterpreted the celebrated classical sculpture of the doomed Trojan prophet Laocoön by casting the prophet as "Agriculture," his two sons as "Manufacturing" and "Commerce," and the death-dealing snake that strangled them the "Railroad Monopoly."23

Open-access antimonopolism presumed that-in the absence of some kind of unfair, immoral, or even illegal special privilege-economic consolidation would be significantly forestalled. While not necessarily noninterventionist, it had certain affinities with the classical nineteenth-century 

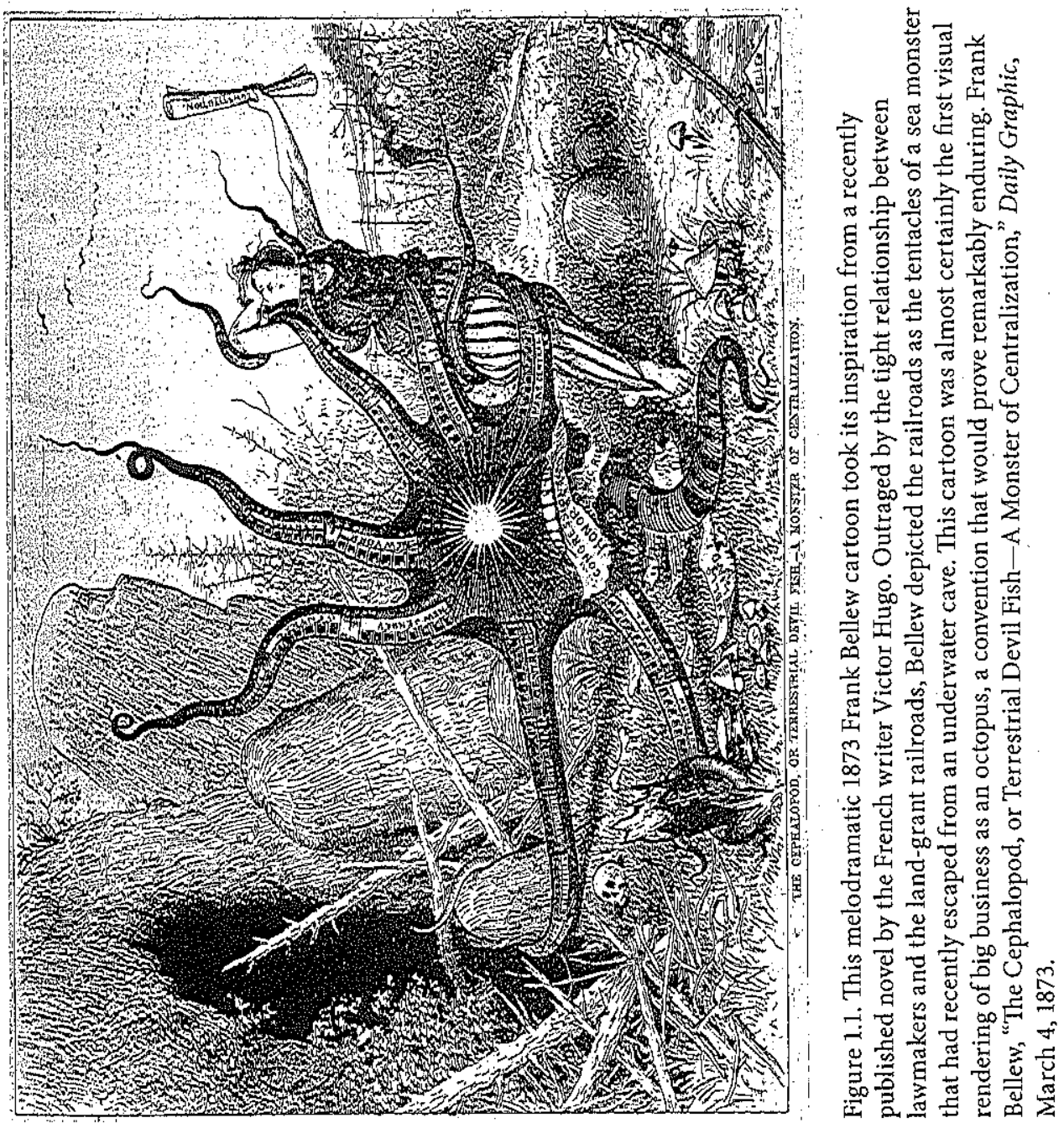

liberal doctrine that its detractors would stigmatize as "laissez-faire." Each placed more faith in market forces than lawmakers and each feared the propensity of regulatory initiatives to strengthen incumbents and weaken insurgents. Its most celebrated journalistic monument was Ida M. Tarbell's searing exposé of John D. Rockefeller's Standard Oil Company, which she serialized in McClure's Magazine beginning in 1902 and published as a book two years later: Tarbell's father had been an independent oilman, and, like. the pre-1881 critics of Western Union, Tarbell took it for granted that, had Rockefeller not been a beneficiary of special privilege, a salutary competition would have prevailed. To illustrate her thesis, Tarbell described in numbing detail the inner history of a thirty-year-old intra-industry set-to involving railroad rebates that she had learned about from her father and read about in the press. ${ }^{24}$

The open-access antimonopolism of Bellew and Tarbell was long on moralism and short on practicality. A related, yet in some ways markedly' different; response to economic consolidation treated the rise of big business as inevitable and advocated permanent government regulation to align the emerging corporate order with the public good.

Among the most celebrated of the consolidationists were the journalists Henry George and Henry Demarest Lloyd. Though each had a well-deserved reputation as a radical, neither was an outsider to the world of proprietary capitalism. Both were urbanites who spent much of their adult lives in big cities-New York City for George, Chicago for Lloyd--and each spent many years reporting for big-city newspapers on the challenges that proprietary capitalists confronted in a world in which they remained a powerful political bloc.

Henry George's antimonopolism grew directly out of his firsthand experience as a journalist at a San Francisco daily. To try to obtain for his newspaper a telegraphic news feed, George journeyed in 1869 to New York City - the same year in which the transcontinental railroad had been completed. Following an unsuccessful meeting at Western Union headquarters, George concluded, correctly, that the news feed would not be forthcoming because Western Union had entered into a collusive relationship with the country's most important news broker, the New York Associated Press. This discovery led George to an epiphany that would give shape to his life's work. Technological innovation, George now understood, could be a curse as well as a blessing-or, as he put it, "progress" for the few could coexist with "poverty" for the many. Having reached this sobering conclusion, George turned 
his attention to the injustice of private land ownership, a monopoly that he regarded as even more pernicious than the collusive relationship between Western Union and the Associated Press. ${ }^{25}$

Lloyd's antimonopolism, like Henry George's, was nurtured during his years as a big-city newspaper journalist. George discovered his life's work in a single blinding flash; for Lloyd, in contrast, his ideas evolved gradually as he climbed the journalistic ladder. Starting out as literary editor for the Chicago Tribune, Lloyd rose through the ranks to become financial editor and then chief editorial writer. Following a quarrel with one of the newspaper's owners--who, as it happens, was Lloyd's father-in-law-he left the paper to become a freelancer. Lloyd lived well. Having learned a good deal about Chicago real estate during his years as a journalist, he astutely parlayed this knowledge into a substantial fortune. In making the case against monopoly power, Lloyd combined firsthand reporting with analytical insights gleaned from state-of-the-art European social science. As a journalist, Lloyd reported dutifully on political scandals, legal entanglements, and legislative infighting-setting the pattern for much of the antimonopoly journalism to follow. As a social-science popularizer, he built on the Victorian reassessment of the classical economics of Adam Smith. The fruits of Lloyd's labors appeared in countless newspaper and magazine articles, as well as in his masterpiece, Wealth Against Commonwealth (1894), an impassioned exposé of the business practices of John D. Rockefeller's Standard Oil.

Like Ida M. Tarbell, who had drawn extensively on Lloyd's reporting in her Standard Oil exposé, Lloyd found much to deplore. Yet unlike Tarbell, Lloyd regarded economic consolidation not as a perverse aberration, but rather as an irreversible social fact. By documenting the rise of the corporate order, Lloyd hoped to hasten the day when Americans would "save the liberties they have inherited" by "winning new ones to bequeath": "Monopoly is business at the end of its journey. It has got there. The irrepressible conflict is now as distinctly with business as the issue so lately met was with slavery."26 Lloyd's task was to craft a narrative so compelling that it would raise the consciousness of his readers to such a pitch that they, too, would share his moral indignation at the injustice that he had revealed: "When it comes to know the facts the human heart can no more endure monopoly than American slavery or Roman empire. The first step to a remedy is that the people care. If they know, they will care. To help them to know and care; to stimulate new hatred of evil, new love of the good, new sympathy for the victims of power, and, by enlarging its science, to quicken the old into a new conscience, this compilation of fact has been made."27

The crux of Lloyd's argument was not economic but moral. Lloyd is justly remembered today as his generation's leading journalistic popularizer of social scientific ideas. The fact-value distinction was not among them. That "science" was the "substance" of the word "conscience" was no mere "verbal accident," Lloyd reminded his readers in the closing paragraph of Wealth Against Commonwealth: "We must know the right before we can do the right.". ${ }^{28}$ Monopoly was objectionable-like slavery-not because it was economically inefficient, but because it was morally pernicious. Its evils had nothing to do with size: mere bigness was not bad. If anything, the vast organizations that dominated the transportation and communications sectors rested on a foundation that was unnecessarily narrow.

The ultimate source of the moral iniquity of monopoly lay in the baleful moral philosophy of which it was the consummate expression. The widespread embrace of the ethically threadbare utilitarianism of the English moral philosopher Jeremy Bentham - who had the temerity to proclaim the tired shibboleth "the greatest happiness of the greatest number" to be a worthy civic ideal-had led, in an age of rapid technological innovation, to the accumulation of vast reservoirs of unregulated power by the supremely selfish individuals who ran the nation's corporations. ${ }^{29}$ To respond, as many antimonopolists did, that the challenge of utilitarianism could be met by harnessing self-interest to the public good through the enactment of legislation establishing regulatory agencies to constrain self-interest, was an unrealistic "dream": "It is to accept the principle of the sovereignty of the self-interest of the individual and apply constitutional checks to it." ${ }^{30}$ For this reason, Lloyd's Wealth Against Commonwealth can be read as a five-hundredpage meditation on the "discovery" that business corrupts politics-an insight that is typically associated not with the late nineteenth-century antimonopolists, but rather with the early twentieth-century muckrakers whose conclusions they did so much to prefigure. ${ }^{3 \mathrm{x}}$

A devout Christian socialist, Lloyd urged Americans to renounce selfinterest and embrace the "greatest happiness of all. ${ }^{n 2}$ To reach the promised land, Lloyd looked to the past. In his search for templates for the good society, Lloyd commended two of the nation's oldest and most venerable institutions: the public school and the Post Office Department. While obviously different, each of these institutions shared a common DNA rooted in a civic 
mandate that transcended the utilitarian pursuit of self-interest: "We are to apply the co-operative methods of the post-office and the public school to many other common toils, to all toils in which private sovereignty has become through monopoly a despotism over the public, and to all in which the association of the people and the organization of processes have been so far developed that the profit-hunting Captain of Industry may be replaced by the public-serving Captain of Industry."33

Journalists provided the antimonopoly movement with its most enduring literary testaments: Henry George's Progress and Poverty (1879), Edward Bellamy's Looking Backward (1888), and Lloyd's Wealth Against Commonwealth (1894). Yet antimonopoly was by no means confined to the press. Among its nonjournalistic champions were the legion of wholesalers and shippers who relied on the railroad and the telegraph to buy and sell. Merchants had nothing against wealth. Yet they resented the accumulation of vast fortunes by corporate moguls who were seemingly unconstrained by market forces.

Among the most earnest of the merchant antimonopolists was Francis $B$. Thurber, the same individual who, following his bankruptcy, would rail against the antimonopolists for their supposed indifference to the iron laws of economics. Thurber was not a deep thinker, and his antimonopolism lacked subtlety. Even so, it was not without a certain unassailable cogency. Recent improvements in the forces of production, Thurber believed, of which the most important were the railroad and the telegraph, had enormously increased the ability of certain powerful men to perform useful labor. Unfortunately, the fruits of innovation remained inaccessible to the rest of the population, having been monopolized by soulless corporations whose owners reaped vast profits by manipulating the terms of trade. To remedy this evil, civic-minded citizens such as Thurber had an obligation to bring it to the attention of the middle and upper classes, since, in his view, the injustices that the railroad and telegraph were daily perpetrating were too abstract and arcane to be fully appreciated by the poor. ${ }^{34}$ To assume that the lower orders could fully comprehend the full magnitude of the depredations that were being wrought by railroad and telegraph corporations defied common, sense. After all, or so Thurber sanctimoniously assumed, only a cosmopolitan merchant like Thurber himself could possibly understand how the system really worked.

Thurber embraced the nineteenth-century liberal commonplace that human labor was the ultimate source of value. Yet he readily conceded that recent technological innovations had fundamentally altered the relationship between work, power, and wealth. With the advent of steam power, a new, nonhuman agency had unexpectedly become the world's greatest labor saver, making it the "greatest creator of wealth in existence." The harnessing of electricity raised an analogous conundrum: could the energy generated by steam and electricity be privately owned? Thurber's answer was an emphatic no. Human beings had the right to own their own labor, but not the energy generated by steam or electricity. This was because these new forms of power were gifts from God: "Like light, or air, or water, they are God's gifts to the human race, and should be possessed and enjoyed by everyone." Tragically, however, the "great middle class" had been largely shut off from the benefits of this new form of power, while the poor found themselves confronted for the first time by employers who, having harnessed the power of steam and electricity, had become "independent" of their exertions. ${ }^{35}$

To draw public attention to the injustices that were being daily perpetrated by the railroad and the telegraph, Thurber organized the National Anti-Monopoly League in 1881. The immediate catalyst for its establishment was the frustration of an influential cohort of New York City-based merchants at the reluctance of Republican state lawmakers to establish a state railroad commission. Though the league aspired to be a "national" organization, it was in fact headquartered in New York City, and during its brief heyday in the 1880 s remained a mouthpiece for the city's proprietary capitalists, who, in this period, counted among their ranks some of the city's wealthiest and most highly respected men. Farmers played no role in the league's founding, and workers were important only as an audience for its appeals. Instead, the league was a publicity machine that had been organized by some of the city's wealthiest merchants to win votes and build a political constituency to regulate the emerging corporate order.

The league attained one of its primary goals in 1882 when the New York state legislature established a railroad commission. Flush with victory, its organizers broadened their agenda to embrace the monopoly question in all of its dimensions. To get their message across, they turned to the press. How else would it be possible to persuade a broad cross section of the electorate of the daily injustices that were being perpetuated by corporations? Central to the league-sponsored media campaign was the launching in 1882 of Justice, a weekly newspaper devoted to "Anti-Monopoly Principles" from the standpoint of the "Rights of the Many as Against the Privileges for the Few." ${ }^{36}$ 
In the next few years, Justice ran hundreds of fact-studded articles detailing corporate abuses, which it supplemented with a sprinkling of antimonopoly cartoons. Among these cartoons was yet another by Frank Bellew. Dubbed "Comparative Bigness" in the explanatory article that accompanied it in the magazine in which it originally appeared, Bellew's cartoon was retitled "Upon What Meat" by the editors of Justice, a high-toned reference to a line from Shakespeare's "Julius Caesar." In this cartoon, which occupied the entire top right column of the newspaper's first page, Bellew compared the "relative proportions" of railroad tycoon William $\mathrm{H}$. Vanderbilt, who at the time was worth $\$ 100$ million, with that of a wealthy man worth $\$ 1$ million -an impressive total even for the most successful proprietary capitalist-and a worker, defined as "small capital and labor," who made ten dollars a week. To make this comparison visually arresting, Bellew hit upon an ingenious conceit: he portrayed Vanderbilt, the millionaire, and the worker as if their wealth were proportional to their height. In such a rendering, Vanderbilt filled the newspaper's column from top to bottom, the millionaire was overshadowed by Vanderbilt's shoe, and the worker was buried at the bottom of an enormous pit so deep that the full length of its shaft could not be fully displayed on the page. "I7 "Is it any wonder," the editor added, with a palpable sense of frustration at the indifference of his readership toward the injustice that Bellew had depicted, "that the people stand evils without general protest even, that the great man has a supreme contempt for them and says, "The public be damned?" (Figure 1.2.) ${ }^{38}$

It is hard to know how many articles Thurber himself may have contributed to Justice, or even if he wrote for it at all. Most Justice articles were unsigned, and many appear to have been recycled from other publications. Yet there can no doubt that Thurber fully shared Bellew's outrage at economic inequality, and, in particular, the rapidly growing wealth gap between the rich and poor. We are "fast becoming a nation of millionaires and tramps," Thurber declared in a public address on "Democracy and Anti-Monopoly" that he delivered in 1883. Such an inegalitarian, class-divided society was most emphatically not what the founders of the republic had had in mind when they had tried to level the playing field for future generations by abolishing primogeniture and entail: "Could they have foreseen the invention of steam and electricity and the consequent enormous development and power of corporate life, can it be doubted that they would have placed adequate checks and limitations thereto?"39

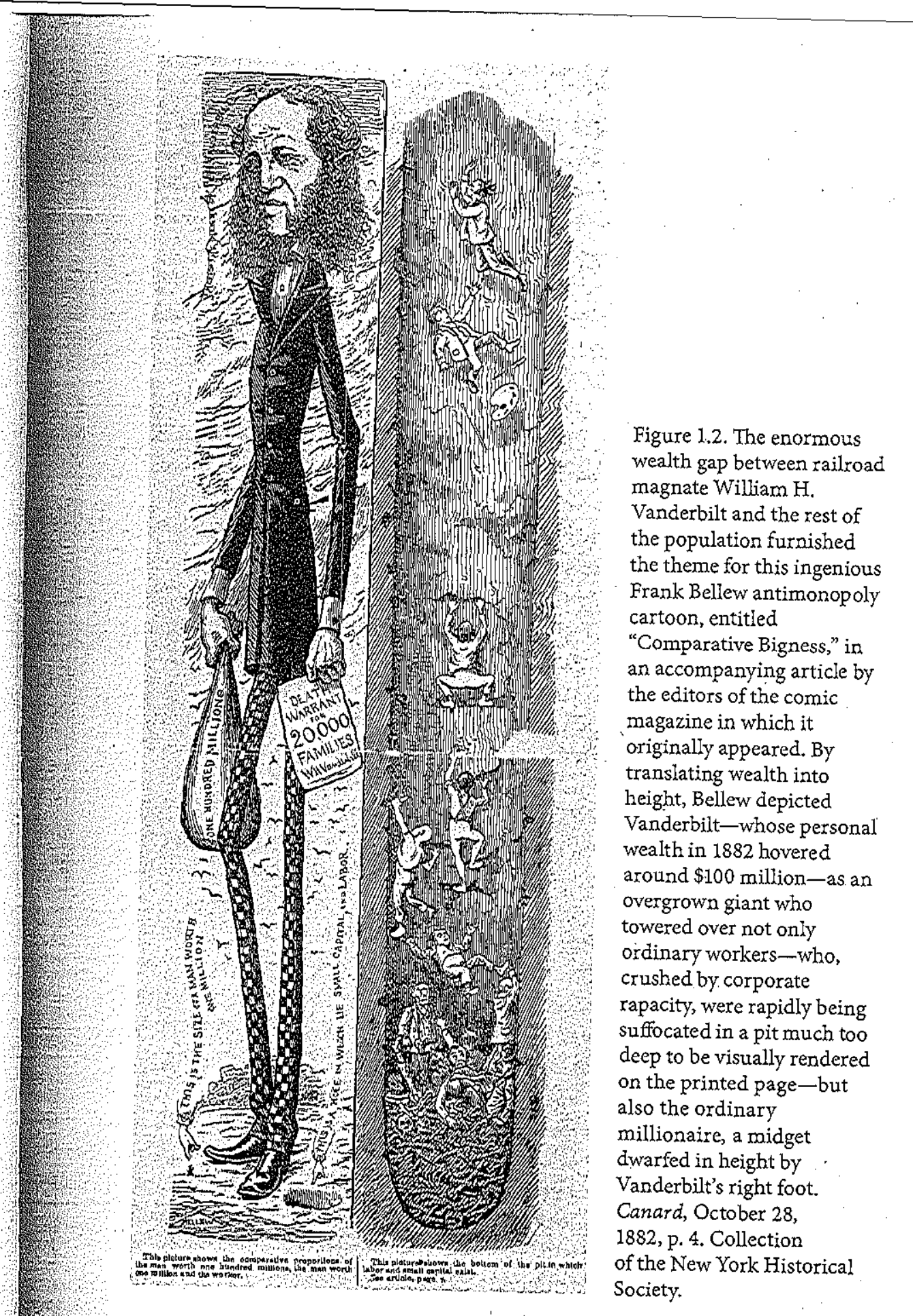
magnate William $\mathrm{H}$.

Vanderbilt and the rest of Thepulation furnished me for this ingenious cartoon, entitled

"Comparative Bigness," in panying article by magazine in which it inally appeared. By height, Bellew depicted erbilt-whose person overgrown giant who towered over not only ordinary workers-who, ed by corporate city, were rapidly being o in a pit much too on the printed page-but also the ordinary onaire, a midget dwarfed in height by erbilt's right foot. 1882, p. 4. Collection Society. 
Thurber aimed his barbs not only at corporations, but also at the corrupt and corrupting influence of corporate-based financial speculation on the press. Like many New Yorkers who read the newspapers or perused Puck's gallery of antimonopoly cartoons, Thurber was deeply troubled by the quality of the financial information upon which every merchant relied. Every well-informed New Yorker understood that speculative high-flyers like Jay Gould routinely planted fake news stories in big-city newspapers that had been designed to trick gullible investors into making foolish investment decisions. ${ }^{40}$ It was by no means unheard of, Lloyd sardonically reported in Wealth Against Commonwealth, for corporate lobbyists to persuade journalists to intentionally misreport antimonopoly speeches. ${ }^{41}$ In such a house of mirrors, Thurber believed, it had become a civic obligation for right-thinking Americans to help subsidize an independent newspaper like Justice. "Subscribe for Justice"-or so ran a solicitation that appeared frequently in its pages - "a Paper whose Opinions are Not for Sale." ${ }^{42}$

Thurber shared Lloyd's conviction that the perils of monopoly were better understood by the few than the many, and, thus, that insiders like himself had a special obligation to publicize the immorality of business practices that the many were regrettably prone to ignore: "The masses do not appreciate how great, many and dangerous have been the attacks made by.corporate monopolies upon our free institutions. Time will not permit me to enumerate many of them, but the following ..."43

The "checks and limitations" on corporate power that Thurber envisioned were regulatory. Confident that lawmakers could set matters right, Thurber had little patience with Lloyd's conviction that government regulation was futile, since it would inevitably become a tool for the few. If the "centralization" of power could be checked, Thurber favored local control. Yet that time had passed: "I am opposed to the centralization of power either in the hands of Government or of corporations, but centralization is a fact staring us in the face and we must see if we cannot make one form of centralization neutralize the other." 44 The only alternative to the countervailing power of government regulation, Thurber declared, was an "anarchy" dominated by men whose "individuality" had become so submerged in a "corporate organization" that it had rendered them "as hard as steel, as pitiless as the storm." 45

Antimonopolists like Thurber and Lloyd spilled a great deal of ink in the 1880 s on the perils of economic consolidation. In pamphlet after pamphlet, newspaper article after newspaper article, and government investigation after government investigation (mostly at the state level), they mounted a searing assault on the corrupt and corrupting business practices that would long echo and reecho in the press. Their indictment was fact-laden, indignant, and morally charged. They aspired not only to change minds, but also to open hearts. Corporate magnates like William H. Vanderbilt, Jay Gould, and John D. Rockefeller had not only clogged the channels of trade; they were conspiring to destroy the republic. ${ }^{46}$

Cartoonists proved adept at translating the antimonopoly appeal into a visually arresting form. The disclosure that Standard Oil had colluded with the railroads to cut costs might not stir the blood. Yet if the oil refiner were transmogrified into an octopus, it became much easier to render legible the consequences of phenomena that were otherwise not easily grasped. ${ }^{47}$ The ecological devastation wrought by Standard Oil's archipelago of big-city refineries was an especially compelling target. After all, the link between its business practices and the noxious fumes that belched forth from its East River refinery just north of Brooklyn was plain for all to see-or, more precisely, to smell. Standard Oil was a "horrible monster," screamed the caption of a haunting antimonopoly cartoon illustrating these hazards that ran in the Daily Graphic in 1880 (Figure 1.3). ${ }^{48}$

The oil-refinery monster conceit was reminiscent of, and was very probably indebted to, the railroad-monsters that Frank Bellew had drawn for the Daily Graphic. Yet its victims were different. No longer had the corporation set its sights on the government, as had Bellew's railroad-monster. Rather, its victim was the multitude of urbanites-including many who the cartoonist plainly depicted as well-to-do-whose air had been poisoned by the foul odors emanating daily from Standard Oil's refinery, a hazard that the cartoonist rendered visually arresting by depicting the source of the malodorous stink that was spreading "poverty, death, and disease" as the outstretched "tentacles" of the oil refinery-monster insidiously extended its reach. 49

The iconography of antimonopoly entered a new and more expansive phase following Jay Gould's takeover of Western Union in January 1881. Nowhere was this more evident than in the New York City-based humor magazines Puck and Judge. Like the Daily Graphic, these magazines appealed to an upscale audience of worldly New Yorkers who reveled in their insidedopester political satire and admired the multicolor chromolithographs that were featured in every issue.

For Joseph Keppler, one of the ablest cartoonists of this or any age, Gould's takeover provided the inspiration for a gallery of stunning antimonopoly cartoons. The first, which appeared within days of Gould's takeover, 


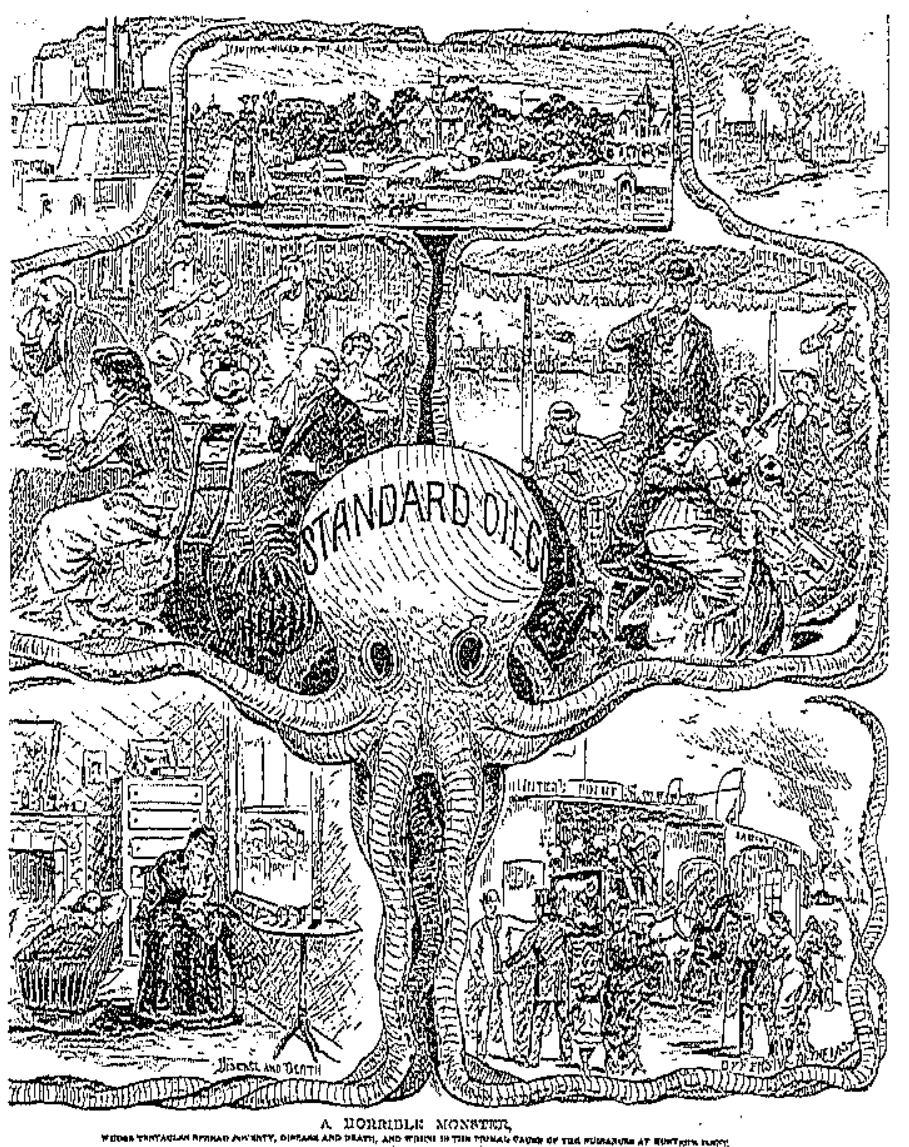

Figure 1.3. The ecological devastation wrought by a Standard Oil refinery just north of Brooklyn inspired this haunting antimonopoly cartoon, in which the corporation became a

"horrible monster" whose tentacles had become noxious fumes that polluted the air, fouled middle-class parlors, and rendered genteel waterside villas uninhabitable. In contrast to Frank Bellew's railroad-monster, the oil refinery-monster had fixed its tentacles not on the government but on the environment.

"Hooper," "A Horrible Monster," Daily Graphic, July $19,1880$. was entitled, fittingly enough, "Consolidated." In the background, telegraph poles bearing the names of telegraph companies that Gould had recently acquired stretched across the land. In the foreground, a gleeful Gould perched comfortably on a playground swing (the "telegraph monopoly") tethered by telegraph wire to statues representing "commerce" and "the press." As Gould glided back and forth, the wires tightened around the statues' necks, strangling them to death. ${ }^{50}$

The republic was "In Danger," screamed the caption for another Keppler cartoon that ran in Puck the following month. This time the threat lay in the corrupt nexus of lawmakers and business interests that Keppler depicted as a snake (labeled "monopoly") that had slithered out of the Capitol, whose alternating stripes bore the names of lawmakers and corporations ("Standard Oil," "Pennsylvania Central Railroad") as well as notorious corruption scandals ("Alaska"). The intended victim of this corrupt nexus-monster was, as it had been so often for Bellew, the country's vaunted civic ideals, as personified by a flag-clad matron whose Phrygian cap, a venerable symbol of freedom, bore the word "Liberty" across its front. Whether or not the republic could be saved remained an open question. "What are you going to do about it?". Puck's mascot asked Uncle Sam, whom Keppler rendered as a kindly yet ineffectual bystander who had yet to make up his mind to take a decisive stand against corruption. ${ }^{51}$

For cartoonists, the answer to the mascot's question depended on one's politics. For Keppler, publicity held the key. Keppler's cartoon "The Monster Monopoly" made this point with particular force. Once again, the grasping corporation took the form of a creature from the deep. This time, however, the monster was not an octopus, but a whale. The whale-which sported Gould's face on its head, and the faces of Gould's collaborators William $\mathrm{H}$. Vanderbilt and Cyrus Field on its tail fins-spouted "monopoly" as it flipped its tail fins to upend a flimsy rowboat ("business"). To the rescue came the press in a sturdy little craft (the "Dauntless") manned by skillful rowers whom the cartoonist identified as "editors." At the helm of the skiff stood Puck's mascot, poised to plunge a harpoon (whose tip bore the talismanic word "antimonopoly") into the whale's side. ${ }^{52}$

Other cartoonists lacked Keppler's confidence in the power of the press. Antimonopolists were in a "Perplexing Position," brooded one Puck cartoonist in late 1881. Now that antimonopoly had gained the endorsement of New York City's corrupt Democratic political machine, Tamimany Hall, it was hard for men of good faith-personified here by the magazine's mascot-to 
choose between the "Monopolyville" of Vanderbilt and Field, and the "Anti-Monopolyville" of Tammany boss John Kelly. Kelly, an opportunistic antimonopolist, held aloft the banner "Down with the Bloated Monopolists" to cynically garner votes while sidelining sincere antimonopolists like Thurber-who was, quite literally, in Kelly's back pocket. ${ }^{53}$ Here the cartoonist raised a challenging question that later historians would long debate: Had merchant antimonopolists like Thurber successfully co-opted the Democratic Party-with its large working-class constituency-or was it the other way around?

The only antimonopoly cartoonist who could rival Bellew and Keppler in sheer inventiveness was. G. Frederick Keller. Unlike Bellew and Keppler, Keller rose to prominence not in New York City, but in San Francisco, where, for a few years in the 1880 s, he published an arresting portfolio of antimonopoly cartoons for the satirical magazine Wasp-the West Coast equivalent of Keppler's Puck. ${ }^{54}$.

Antimonopolists differed on many issues of strategy and tactics, yet on one point consensus prevailed. The wellspring of the antimonopoly movement lay not in the hinterland, but in the ration's largest cities-and, in particular, in New York, Brooklyn, Chicago, and San Francisco-while its earliest and most influential champions were neither farmers nor workers, but proprietary capitalists and the journalists who covered their beat. Indeed, it would be hard to point to a single antimonopoly theme that would be championed in the 1890s and beyond by a farm or labor leader that had not appeared before 1880 in a big-city newspaper or magazine. If New York City was a "monied metropolis" in which merchants and manufacturers formed a durable alliance, as one historian has claimed, then it was also an antimonopoly metropolis in which proprietary capitalists collaborated with journalists to expose the abuses of the emerging corporate order.

The vocabulary of antimonopoly was urbane and sophisticated, as one might have anticipated, rooted as it was in the moral philosophy of the eighteenth-century Scottish Enlightenment and the political econorny of mid-nineteenth-century British and Continental social science. So too was its visual iconography. Bellew had been born in British India, and drew much of his inspiration from the London comic magazine Punch, to which he occasionally contributed. Keppler, in turn, hailed from Vienna, and would deploy to good advantage in Puck compositional techniques that he had absorbed from the Baroque architecture, sculpture, and painting of the Hapsburg Empire that he remembered from his youth.
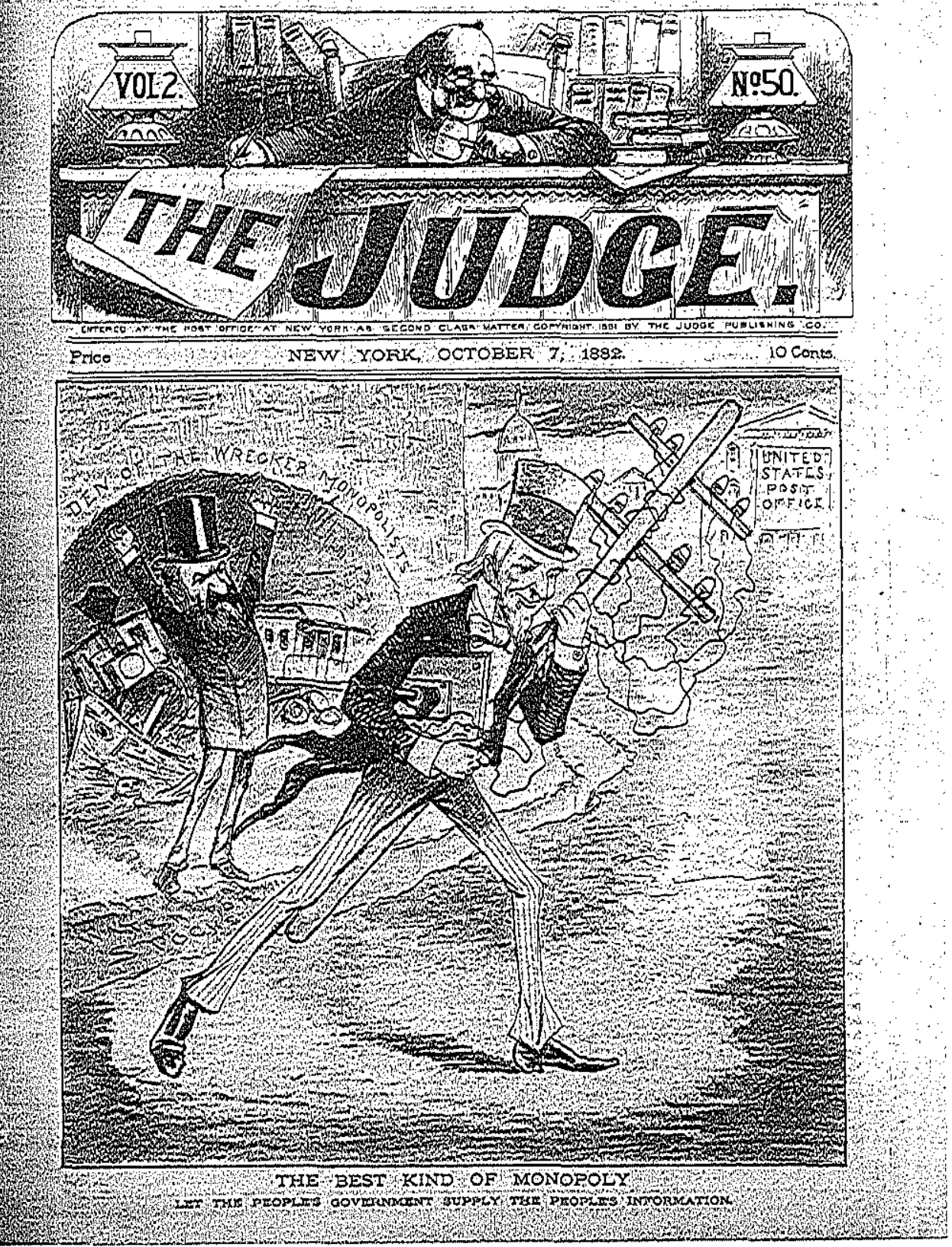

Figure 1.4. "The Best Kind of Monopoly," ran the caption for this hopeful 1882 James A. Wales antimonopoly cartoon endorsing the absorption of the telegraph by the Post Office Department. "Let the People's Government Supply the People's Information," the caption proclaimed, articulating a civic ideal that appealed to East Coast proprietary capitalists and that would soon be picked up by populists in the South and West. James A. Wales, "The Best Kind of Monopoly," Judge 2 (October 7, 1882): 1 . 
The urban pedigree of the antimonopoly movement was particularly conspicuous in its third, nationalist variant. Having accepted the inevitability of economic consolidation, nationalist antimonopolists took the further step of endorsing government ownership.

Government ownership today is often looked upon as a bizarre and foreign idea alien to the country's supposedly antistatist past. In fact, it has a distinguished American pedigree. For many late nineteenth-century antimonopolists, including Lloyd and Edward Bellamy, the much-touted success of the Post Office Department silenced any doubts regarding its practicality. For many Americans in the 1880s, 1890s, and 1900s-and not just for socialists, radicals, and Bellamyite nationalists-government ownership seemed far more compelling than corporate control. It was, after all, an age in which many Americans defended the public over the private, and not just for nationwide combines such as Western Union, but also for municipal franchise corporations with a mandate to provide the entire populationand not just that segment of the population who had the ability to pay-with gas, water, public transportation, and even telephone service. ${ }^{55}$

The relative equanimity with which Americans contemplated government ownership owed much to the antimonopoly appeal. For the antimonopoly cartoonist, the corporation was invariably a malign and often frightening monster. The republic's civic ideals, in contrast, were typically personified as a gracious and ingratiating, if often somewhat ineffectual, Uncle Sam. Government ownership was the "Best Kind of Monopoly," declared cartoonist James A. Wales in a forthright endorsement of the congressional buyout of the telegraph network that ran in the resolutely establishmentarian humor magazine Judge in October 1882. To illustrate this theme, Wales depicted an unusually resolute Uncle Sam wrestling a telegraph pole out of Jay Gould's hands and confidently striding out of the "den of the wrecker monopolists" and, to Gould's immense chagrin, across the river of watered stock that the "wrecker" could not ford and on to its future home in the Post Office Department. Like a latter-day Moses, Wales's Uncle Sam had led his people out of Egypt, across a river that their tormentor could not cross, and toward the promised land. The moral was unmistakable: government ownership was the solution to the problem that corporation-enabled speculative finance had spawned. Lest some dimwitted subscriber miss the point, Wales's caption spelled it out: "Let the People's Government Supply the People's Information" (Figure 1.4). ${ }^{56}$
The specter of corruption provided antimonopoly cartoonists with a wealth of material. The trick was to render this danger visually compelling. To help convince his audience that the republic was truly "In Danger," Keppler depicted the corrupt nexus of lawmakers and business interests as a slithering snake ("monopoly") that had wrapped itself around the congressional dome. ${ }^{57}$ The specter of corruption would be rendered even more compellingly a few years later in Keppler's "Bosses of the Senate," in which a phalanx of overfed lobbyists for different monopolies (the "Standard Oil Trust," the "Sugar Trust," the "Copper Trust") had shut the public out of the legislative chamber. ${ }^{58}$

Equally artful was Grant E. Hamilton's "In the Clutch of a Grasping Monopoly," an 1888 slap at the nation's largest telephone company, in which the "Bell Telephone Monopoly" became a grasping spider angling to entrap the federal legislature in its web. ${ }^{59}$ The corporation-monster hybrid reached something of an apotheosis in 1904, when Keppler's son, Joseph Jr.,-who, like his father, was a cartoonist for Puck-updated the by-then venerable rendering of the monopoly as an octopus to accuse the Standard Oil Company of trying to corrupt the presidency. In Joseph Jr.'s, rendering, the Standard Oil octopus had alseady wrapped its tentacles around the state legislatures and Congress, and had set its sights - "Next!"-on the ultimate prize: 'Theodore Roosevelt's White House..$^{60}$ As if to answer Keppler's implicit question, one of his colleagues reassuringly responded the following year with news that the "Standard Oil Serpents" of Rockefeller and Henry H. Rogers had not overmastered Roosevelt (the "Infant Hercules"), but, instead, that the youthful president was successfully wrestling them to the ground. ${ }^{61}$

$$
* * *
$$

This essay has traced the popularization in the 1880s of an antimonopoly critique of corporate capital that had been crafted by proprietary capitalists in conjunction with their journalistic admirers. The central role played in the antimonopoly movement by these groups, rather than by farmers and workers, has long been obscured by the mistaken assumption that late nineteenthcentury politics revolved around a contest between the people and the interests, with the interests being more or less congruent with business. In fact, the antimonopolists regarded the interests of the people and the interests of proprietary capitalists to be fundamentally aligned. For them, the 
primary fault line was not the people versus business, as a later generation of progressives would contend. Rather, it was business versus monopoly, a very different configuration that aligned business with the people and both against monopoly. This distinction will remain obscure so long as historians continue to view the period through a Manichean people-versus-the-interests lens. "Monopoly is not business," explained an editorialist in a New York City periodical in 1884 , in a particularly pithy distillation of the conventional wisdom. On the contrary, monopoly "kills business," an accusation that antimonopolists made repeatedly not only in stirring prose but also in the stunning visual iconography that remains one of the movement's most enduring legacies. ${ }^{62}$

The pivotal role of proprietary capitalists in the enactment of late nineteenth-century regulatory legislation is well known. New York City merchants drafted key provisions of the Interstate Commerce Act in 1887, and shippers rather than farmers led the fight for the establishment of state-level railroad commissions - a fact that has long been obscured by the uncritical adoption by historians of the once sneering dismissal by seaboard elites of this legislation as farmer-backed "granger laws." 63

This revisionist characterization of the antimonopoly movement rests not only on an analysis of the divergent economic interests of proprietary and corporate capitalists, but also on the media politics of its critics and supporters. This analysis calls into question the propensity of historians to characterize the media politics of the period as tawdry and superficial, the rise of the corporate order as uncontested, and the progress of economic consolidation as unchallenged. Only in history books did antimonopoly bubble up more or less organically from the agricultural hinterland, with little or no input from proprietary capitalists in the nation's major cities. The ubiquity of such a flat, one-dimensional, and fundamentally mistaken people-versus-the-interests story line has its origins not only in the wishful thinking of historians and the gullibility of journalists, but also, and much more insidiously, in the publicity campaign mounted by big-business lobbyists such as Francis B. Thurber. Thurber's post-1893 anti-antimonopoly counteroffensive had been intentionally designed to sabotage the antimonopoly movement by blaming it on farmers and workers, two groups far less powerful-and for this reason markedly less threatening to the status quothan proprietary merchants. It was, in short, the mirror image of the proantimonopoly campaign that Thurber himself had led in the 1880 s, prior to his bankruptcy, to protect the interests of proprietary capital against a rising-though still morally vulnerable-corporate order.

The failure of all but a' tiny handful of historians to fully grasp the character and significance of the late nineteenth-century antimonopoly movement is a testament not only to the extent to which historians have misunderstood the past, but also to the way the past has come to be remembered. By ignoring the interests of proprietary capitalists and the visions of the journalists who championed their cause, historians have provided yet one more reason to perpetuate the seductive, yet highly misleading, peopleversus-the-interests mythology that had led so many to dismiss the 1880 s as a reactionary "Gilded Age." The recovery of these neglected voices reminds us of the extent to which this decade deserves to be remembered-no less than the Progressive Era for which the antimonopoly movement of the $1880 \mathrm{~s}$ would serve as a prelude, inspiration, and goad-as an age of reform. ${ }^{64}$ 
1. See, for example: Paul Starr, The Creation of the Media (New York: Basic Books, 2004); Michael Schudson, Discovering the News (New York: Basic Books, 1981); Michele Hilmes, Radio Voices (Minneapolis: University of Minnesota Press, 1997); David Greenberg, Republic of Spin (New York: W. W. Norton, 2016); Kathryn Brownell, Showbiz Politics (Chapel Hill: University of North Carolina Press, 2014); Susan Douglas, "Presidents and the Media," in Brian Balogh and Bruce J. Schulman, eds., Recapturing the Oval Office (Ithaca, N.Y.: Cornell University Press, 2015); and Lawrence and Cornelia Levine, The People and the President (Boston: Beacon Press, 2002).

2. Michael Schudson, "News, Public, Nation," American Historical Review 107 (April 2002): 481.

3. Chris Daly, "The Historiogxaphy of Journalism History, Part 1: An Overview," American Journalism 26 (Winter 2009): 141.

4. John Nerone, "Does Journalism Matter?" American Journalism 28 (Autumn 2011): 7.

5. Robert W. McChesney, "Communication for the Hell of It: The Triviality of U.S. Broadcasting History," Journal of Broadcasting and Electronic Media 40 (Fall 1996): $540-52$.

6. See for example, Starr, Creation of the Media; Richard R. John, Spreading the News: The American Postal System from Franklin to Morse (Cambridge, Mass.: Harvard University Press, 1995); Richard R. John, Network Nation: Inventing American Telecommunications (Cambridge, Mass.: Belknap Press of Harvard University Press, 2010); Chris Daly, Covering America: A Narrative History of a Nation's Journalism (Amherst: University of Massachusetts Press, 2012); Michele Hilmes, Network Nations: A Transnational History of British and American Broadcasting (London: Routledge, 2011); and Allison Perlman, Public Interests: Media Advocacy and Struggles over U.S Television (New Brunswick, N.J.: Rutgers University Press, 2016).

\section{Proprietary Interest}

1. Francis B. Thurber, "The Right to Combine," Journal of Social Science 37 (December 1899): 225-26. For assistance, I am grateful to Elizabeth Benn, John Evans, 
Nancy R. John, Heather Cox Richardson, Bruce J. Schulman, Mark Wahlgren Summers, Julian E. Zelizer, and two anonymous referees.

2. Thurber, "Right to Combine," 215.

3. 15 U.S.C. $\$ \$ 1-7$ (1890).

4. "Records," vol. 1, Boston Wholesale Grocers' Association, October 26, 1905, Baker Library, Harvard Business School, Boston, Massachusetts. I am grateful to Mookie Kideckel for bringing this document to my attention.

5. The concept of "big business" has long been a favorite of historians, even though it is notoriously hard to define. The phrase itself only rarely appeared in print before 1900; a Google NGram search reveals that its occurrence spiked up rapidly between 1900 and 1920. For a recent overview, see Youssef Cassis, "Big Business," in Geoffrey Jones and Jonathan Zeitlin, ed., Oxford Handbook of Business History (New York: Oxford University Press, 2007), 171-93.

6. Not all merchants, of course, were men. Yet, since the wealthiest and most powerful merchants were men (as well as all the most prominent merchant-antimonopolists), it makes sense to use the male pronoun here to describe the group.

7. David Paul Nord, "The Urban Newspaper and the Victorian City," in Richard R. John and Jonathan Silberstein-Loeb, ed., Making News: The Political Economy of Journalism in Britain and America from the Glorious Revolution to the Internet (New York: Oxford University Press, 2015), 73-106; Richard R. John, "Markets, Morality, and the Media: The Election of 1884 and the Iconography of Progressivism," in Gareth Davies and Julian E. Zelizer, ed., America at the Ballot Box: Elections and Political History (Philadelphia: University of Pennsylvania Press, 2015), 75-97.

8. Lee Benson, Merchants, Farmers, and Railroads: Railroad Regulation and New York Politics, 1850-1887 (Cambridge, Mass.: Harvard University Press, 1953); George Hall Miller, Railroads and the Granger Laws (Madison: University of Wisconsin Press, 1971); Scott C. James, Parties, Presidents and the State: Electoral College Competition, Party Leadership, and Democratic Regulatory Choice, 1884-1936 (Cambridge: Cambridge University Press, 2000).

9. Richard R. John, "Robber Barons Redux: Antimonopoly Reconsidered," Enterprise and Society 13 (March 2012): 3-5.

10. Richard R. John, Network Nation: Inventing American Telecommunications (Cambridge, Mass.: Belknap Press of Harvard University Press, 2010), 124-26, 175-76.

11. Charles Postel, The Populist Vision (New York: Oxford University Press, 2007). See aiso Norman Pollack, The Just Polity: Populism, Law, and Human Welfare (Urbana: University of Illinois Press, 1987).

12. John, Network Nation, chap. 11.

13. The long and deliberate campaign to legitimize the managerial corporation, including, in particular, the key role in this development that was played by specialists in corporate public relations (a profession called into existence to perform precisely this task), has been explored with insight and wit in Roland Marchand, Creating the Corporate Soul: The Rise of Public Relations and Corporate Imagery in American Big Business (Berkeley: University of California Press, 1998).

14. John, Network Nation, chap. 4.

15. The unnatural monopoly argument has inspired three notable books on the history of the transcontinental railroad: Robert William Fogel, The Union Pacific Railroad: A Case in Premature Enterprise (Baltimore: Johns Hopkins University Press, 1960); Robert W. Fogel, Railroads and American Economic Growth: Essays in Econometric History (Baltimore: )ohns Hopkins University Press, 1964); and Richard White, Railroaded: The Transcontinentals and the Making of Modern America (New York: W. W. Norton, 2011).

16. John, Network Nation, 156-70.

17. Bellew's vistal rendering of Uncle Sam depicted him as the weak and ineffectual rival of John Bull, a stand-in for the British government. John Bull supported granting subsidies to the Cunard Steamship Company to carry the transatlantic maid; Uncle Sam refused to lavish an analogous privilege on Edward $\mathrm{K}$. Collins, Cunard's American rival. Frank Bellew, "Collins and Cunard: Raising the Wind; Or, Both Sides of the Story," Lantern, March 13, 1852.

18. For more on the visual iconography of antimonopoly, see John, "Markets, Morality, and the Media:"

19. Online galleries of antimonopoly cartoons can be found at websites hosted by National Humanities Center and Smith College economics professor Mark Aldrich: http://nationalhumanitiescenter.org/pds/gilded/power/text1/octopusimages .pdf; http://sophia.smith.edu/ maldrich/home.htm. Another resource is the innovative online cartoon archive "Politics in Graphic Detail," curated by the Historical Society of Pennsylvania: https:/hsp.org/history-online/historic-images-new -technologies.

20. Frank Bellew, "The Cephalopod, or Terrestrial Devil Fish-A Monster of Centralization," Daily Graphic, March 4, 1873.

21. Frank Bellew, "The American Frankenstein," Daily Graphic, March 18, 1873.

22. Frank Bellew, "The American Frankenstein," Daily Graphic, April 14, 1874.

23. Frank Bellew, "The Modern Laocoön,". Daily Graphic, April 25, 1874.

24. Ida M. Tarbell, The History of the Standard Oil Company (New York: McClure, Phillips, 1904).

25. John, Network Nation, 146.

26. Henry Demarest Lloyd, Wealth Against Commonwealth (New York: Harper \& Brothers, 1894), 512, 532.

27. Ibid., 535 .

28. Ibid.

29. Ibid., 506. 
30. Ibid., 533 .

31. Richard L: McCormick, "The Discovery That Business Corrupts Politics: A Reappraisal of the Origins of Progressivism," American Historical Review 86 (April 1981): 247-74.

32. Lloyd, Wealth Against Commonwealth, 507.

33. Ibid., 534

34. Francis B. Thurber, "Steam and Electricity," International Review 2 (September 1875): 633 .

35. Ibid., 631 .

36. Justice, September 2, 1882.

37. Frank Bellew, "Upon What Meat," Justice, November 11, 1882, 1; "Comparative Bigness," Canard, October 28, 1882, 7. Bellew drew his Vanderbilt cartoon for Canard, a short-lived humor magazine, where it appeared, sans caption, on page 4. To help interested readers who might not quite get the point, the cartoon. was accompanied by a brief explanation along with an invitation to check out the accompanying article on page 7; this article was entitled "Comparative Bigness." Given the limited familiarity of today's audience with the Shakespearean allusion ("Upon What Meat") that the editors of Justice hit upon as a title for Beliew's hitherto untitled cartoon, as well as the likelihood that Bellew had nothing to do with its selection, "Comparative Bigness" would seem to be the better title for the cartoon, even though it did not run on the same page on which the cartoon had originally appeared.

\section{Bellew, "Upon What Meat."}

39. Francis B. Thurber, Democracy and Anti-Monopoly (Brooklyn: n.p., 1883), 13.

40. John, "Robber Barons Redux," 16-20.

41. Lloyd, Wealth Against Commonwealth.

42. Justice, April 4, 1885, 11.

43. Thurber, Democracy and Anti-Monopoly, 9.

44. Ibid., 15.

45. Ibid., 14, 15.

46. John, "Markets, Morality, and the Media," 75-97.

47. "The Standard Oil Octopus," Daily Graphic, February 4, 1879; Frank Beard, "The Monster Monopoly," Judge 6 (July 9, 1884): 16.

48. "Hooper," “A Horrible Monster," Daily Graphic, July 19, 1880.

49. Îbid.

50. Joseph Keppler, "Consolidated," Puck 8 (January 26, 1881): centerfold.

51. Joseph Keppler, "In Danger," Puck 8 (February 9, 1881): centerfold.

52. Joseph Keppler, "The Monster Monopoly," Puck 10 (January 25, 1882). centerfold.

53. "O. K.," "Puck's Pexplexing Position-Between Two Evils," Puck 10 (October 12,1881$): 1$.
54. G. Frederick Keller, "The Modern St. George," Wasp 6 (April 9, 1881); Keller, "The Coming Mar," Wasp 6 (May 20, 1881); Keller, "The Curse of California," Wasp 9 (August 19, 1882).

55. Yohn, Network Nation, chap. 8.

56. James A. Wales, "The Best Kind of Monopoly," Judge_2 (October 7, 1882): 1

57. Keppler, "In Danger."

58. Joseph Keppler, "The Bosses of the Senate," Puck 24 (January 23, 1889) centerfold.

59. Grant E. Hamilton, "In the Clutch of a Grasping Monopoly," Judge 14 (April 7 1888): 16 .

60. Joseph Keppler Jr., "Next!" Puck 56 (September 7, 1904): centerfold. Joseph Jr. was originally known as Udo; he changed his first name to honor the memory of his father shortly after his father's death in 1894 .

61. Frank A. Nankivell, "The Infant Hercules and the Standard Oil Serpents," Puck 59 (May 23, 1906): I.

62. "Not Business, but Monopoly," Daily, Graphic, October 11, 1884.

63. Benson, Merchants, Farmers, and Railroads; Millex, Railroads and the Granger Laws; James, Parties, Presidents and the State.

64. Rebecca Edwards, Richard R. John, and Richard Bensel, "Forum: Should We Abolish the "Gilcled Age'?" Journal of the Gilded Age and the Progressive Era 8, no. 4 (2009): 461-85. See also Yames Livingston, "The Myth of a "Second Gilded Age,". Chronicle Review: January 31, 2016, accessed May 2, 2016, http://chronicle.com/article The-Myth-of-a-Second-Gilded/235072?cid=cpl.

\section{Progressive Political Culture and the Widening Scope of} Local Newspapers, 1880-1930

1. Robert Ezra Park, "The Natural History of the Newspaper," in Robert Ezra Park, Ernest Watson Burgess, Roderick Duncan McKenzie, and Louis Wirth, ed, The City (Chicago: University of Chicago Press, 1925), 85.

2. Ibid.

3. Alfred McClung Lee, The Daily Newspaper in America: The Evolution of a Social. Instrument (New York: Macmillan, 1937), 323.

4. For example, see "New York Now Has Seven Levels of Transit," New York World, March 14, 1909, cover of special "Transformation of New York" section. As reprinted in Nicholson Baker and Margaret Brentano, eds., The World on Sunday: Graphic Art in Joseph Pulitzer's Newspaper 1898-1911 (New York: Bulfinch Press, 2005), 113.

5. Louis M. Lyons, Newspaper Story: One Hundred Years of the Boston Globe (Cambridge, Mass.: Belknap Press, 1971), 113

6. New York World, June 17, 1906, magazine section, 2, as reprinted in Baker and Brentano, eds., The World on Sunday, 88. 


\section{MEDIA NATION}

Series Editors

Margot Canaday, Glenda Gilmore,

Michael Kazin, Stephen Pitti, Thomas J. Sugrue

Volumes in the series narrate and analyze political and social change in the broadest dimensions from 1865 to the present, including ideas about the ways people have sought and wielded power in the public sphere and the language and institutions of politics at all levels-local, national, and transnational. The series is motivated by a desire to reverse the fragmentation of modern U.S.

history and to encourage synthetic perspectives on social movements and the state, on gender, race, and labor, and on intellectual history and popular culture.

\section{The Political History of News in Modern America}

\author{
Edited by
}

Bruce J. Schulman

and

Julian E. Zelizer $\overline{\text { PENN }}$

UNIVERSITY OF PENNSYLVANIA PRESS

PHILADELPHIA 
Printed in the United States of America

$$
\text { on acid-free paper }
$$

10987654321

Introduction

1. Proprietary Interest: Merchants, Journalists, and Antimonopoly in the $1880 \mathrm{~s}$

Richard R. John

2. Progressive Political Culture and the Widening Scope of Local Newspapers, 1880-1930

Julia Guarneri

3. The Ominous Clang: Fears of Propaganda from World War I to World War II

David Greenberg

4. When the "Mainstream Media" Was Conservative: Media Criticism in the Age of Reform Sam Lebovic

5. "We're All in This Thing Together": Cold War Consensus in the Exclusive Social World of Washington Reporters Kathryn McGarr

6. Objectivity and Its Discontents: The Struggle for the Soul of American Journalism in the $1960 \mathrm{~s}$ and $1970 \mathrm{~s}$ Matthew Pressman 